Andrea Casati $M D$, Guido Fanelli MD, Elisabetta Casaletti MD, Eleonora Colnaghi MD, Valeria Cedrati MD, Giorgio Torri MD

\section{Clinical assessment of target-controlled infusion of propofol during moni- tored anesthesia care}

Purpose: To determine the plasma concentrations of propofol required to achieve different levels of sedation during monitored anesthesia care.

Methods: Sixty ASA I-II, 18-65 yr-old patients, received a target-controlled continuous iv infusion of propofol. The target plasma concentration of propofol $\left(C \mathrm{p}_{\mathrm{t}}\right)$ was initially set at $0.4 \mu \mathrm{g} \cdot \mathrm{ml}^{-1}$. Two minutes after calculated equilibrium between plasma and effect-site concentrations, the $\mathrm{Cp}_{\mathrm{t}}$ of propofol was increased by $0.2 \mu \mathrm{g} \cdot \mathrm{ml}^{-1}$ steps until the patient showed no reaction to squeezing the trapezius. The level of sedation was assessed immediately before each increase in propofol $C p_{t}$ using the Observer's Assessment of Alertness/Sedation (OAAVS) scale.

Results: The $C p_{t}$ of propofol required to induce lethargic response to name was $1.3 \mu \mathrm{g} \cdot \mathrm{ml}^{-1}\left(5^{\circ}\right.$ and $95^{\circ}$ percentiles: $\left.1.0-1.8 \mu \mathrm{g} \cdot \mathrm{ml}^{-1}\right)$, to obtain response after loud and repeated calling name was $1.7 \mu \mathrm{g} \cdot \mathrm{ml}^{-1}(1.2-2.2$ $\left.\mu \mathrm{g} \cdot \mathrm{ml}^{-1}\right)$, to obtain response after prodding or shaking was $2.0 \mu \mathrm{g} \cdot \mathrm{ml}^{-1}\left(1.6-2.6 \mu \mathrm{g} \cdot \mathrm{ml}^{-1}\right)$, to obtain response after squeezing the trapezius was $2.4 \mu \mathrm{g} \cdot \mathrm{ml}^{-1}\left(1.8-3.0 \mu \mathrm{g} \cdot \mathrm{ml}^{-1}\right)$. Patients showed no response after squeezing the trapezius at $2.8 \mu \mathrm{g} \cdot \mathrm{ml}^{-1}\left(2.0-3.6 \mu \mathrm{g} \cdot \mathrm{ml}^{-1}\right)$. Correlation between $C \mathrm{p}_{\mathrm{t}}$ propofol and sedation scores were $\mathrm{r}=$ $0.76, P<0.0001$.

Conclusions: Target-controlled infusion of propofol provided easy and safe management of intraoperative sedation, allowing fast and predictable deepening in the level of sedation, while minimizing systemic side effects of intravenous sedation due to the minimal risk of overdosing the drug.

Objectif : Déterminer les concentrations plasmatiques de propofol nécessaire pour fournir différents niveaux de sédation monitorés.

Méthode : Soixante patients ASA I-II de 18-65 ans ont reçu une perfusion continue de propofol iv à cible contrôlée. La concentration plasmatique ciblée de propofol $\left(C \mathrm{p}_{c}\right)$ était d'abord de $0,4 \mu \mathrm{g} \cdot \mathrm{ml}^{-1}$. Deux minutes après avoir atteint l'équilibre entre la concentration plasmatique et celle du site d'effet, la $C_{p_{c}}$ de propofol a été augmenté par paliers de $0,2 \mu \mathrm{g} \cdot \mathrm{ml}-1$ jusqu'à ce que le patient ne réagisse plus à une pression sur le trapèze. Le niveau de sédation a été évalué immédiatement avant chaque augmentation de la $C p_{c}$ de propofol à l'aide de l'échelle de cotation de la vigilance par l'observateur/sédation (CVO/S).

Résultats : $L a C \mathrm{P}_{\mathrm{c}}$ de propofol nécessaire pour induire une réaction léthargique du patient à l'appel de son nom était de $1,3 \mu \mathrm{g} \cdot \mathrm{ml}^{-1}$ ( $5^{=}$et 95 percentiles : $1,0-1,8 \mu \mathrm{g} \cdot \mathrm{ml}^{-1}$ ), pour obtenir une réaction après l'appel du nom répété et à voix forte était de $1,7 \mu \mathrm{g} \cdot \mathrm{ml}^{-1}\left(1,2-2,2 \mu \mathrm{g} \cdot \mathrm{ml}^{-1}\right)$, pour réagir à une poussée ou une secousse, 2.0 $\mu \mathrm{g} \cdot \mathrm{ml}^{-1}\left(1.6-2.6 \mu \mathrm{g} \cdot \mathrm{ml}^{-1}\right)$, et pour réagir à une pression sur le trapèze, $2,4 \mu \mathrm{g} \cdot \mathrm{ml}^{-1}\left(1,8-3,0 \mu \mathrm{g} \cdot \mathrm{ml}^{-1}\right)$. Les patients n'ont pas réagi à la pression sur le trapèze avec une concentration de $2,8 \mu \mathrm{g} \cdot \mathrm{ml}^{-1}\left(2,0-3,6 \mu \mathrm{g} \cdot \mathrm{ml}^{-1}\right)$. La corrélation entre la $\mathrm{Cp}_{\mathrm{c}}$ de propofol et les niveaux de sédation a été aussi observée, $r=0,76, P<0,0001$.

Conclusion : La perfusion de propofol à cible contrôlée fournit une ligne de conduite facile et sûre pour la sédation peropératoire, permettant l'approfondissement rapide et prévisible de la sédation tout en réduisant les effets secondaires généraux de la sédation intraveineuse causés par le risque minimal d'une surdose de médicament.

From the University of Milan - Department of Anesthesiology, IRCCS H. San Raffacle, Via Olgettina 60, 20132 Milan, Italy. Address correspondence to: Dr A. Casati. Phone: 39-2-26432656; Fax: 39-2-26412823; E-mail: casati.andrea@hsr.it Accepted for publication December 12, 1998 
$\mathrm{T}$ HE combination of local or regional anesthesia and sedation has become increasingly popular for operations in which the procedure could be considered to be minor but excessive patient anxiety results in low acceptance and co-operation. ${ }^{1}$ All sedative/hypnotic drugs produce dose dependent depression of the central nervous system (CNS), and the rapidity with which a patient can move from a minimally depressed state of consciousness to general anesthesia as well as the variations in individual patient responses to the same dose of a sedative drug may be hardly predictable.

Propofol is a short acting intravenous anesthetic with a rapid recovery profile ${ }^{2}$ and amnesic effects similar to those of midazolam at equisedative doses. ${ }^{3}$ Recently, target-controlled infusion systems (TCI) have become available for use with propofol, allowing the more rapid achievement and maintenance of the desired level of anesthesia. ${ }^{4-6}$ However, we were unaware of clinical studies assessing the use of targetcontrolled infusion systems of propofol to produce different levels of sedation.

The purpose of this prospective investigation was to provide more information on the plasma concentrations of propofol required to achieve different levels of sedation during monitored anesthesia care.

\section{Materials and methods}

After approved by the local Institutional Review Board and informed consent, 60 ASA I-II, 18-65 yrold patients scheduled for elective minor orthopedic ankle and foot procedures under regional anesthesia with an expected duration of one hour were studied. Patients with a history of allergic reactions to propofol or local anesthetic drugs, as well as pregnant women, patients with a history of esophageal reflux, known or predicted difficult airway (e.g. Mallampati classification 3-4), and patients with a history of neurological or psychiatric disease were excluded.

Without premedication, a combined sciatic-femoral nerve block was performed with the aid of a nerve stimulator using $25-30 \mathrm{ml}$ mepivacaine $2 \%,{ }^{7,8}$ After adequate nerve block for surgery had been confirmed by loss of pin-prick sensation at the surgical field, baseline hemodynamic variables were recorded. Then, a continuous intravenous infusion of propofol (Diprivan, Zeneca Pharmaceuticals, Italy) was started using a target-controlled infusion system (Diprifusor@, Fresenius, Italy). The pharmacokinetic data set applied by the 'Diprifusor®' TCI system includes a three-compartment pharmacokinetic model with the pharmacokinetic parameters introduced by Marsh and colleagues to improve predictive performance, and a recent software modification which also dysplays the estimated effectsite concentration of propofol. ${ }^{9-11}$ The propofol infusion was set at a target plasma concentration $\left(\mathrm{Cp}_{\mathrm{r}}\right)$ of $0.4 \mu \mathrm{g} \cdot \mathrm{ml}^{-1}$. Since the site of drug effect for propofol is the brain, and there is a delay between achieving a target plasma concentration and its equilibration with its effect site, ${ }^{12}$ the target plasma concentration of propofol was progressively increased by $0.2 \mu \mathrm{g} \cdot \mathrm{ml}^{-1}$ steps two minutes after the equilibrium between plasma and calculated effect-site concentrations had been achieved. Assessments of sedation level were performed prior to increasing the target concentration of propofol by a trained independent observer using the Observer's Assessment of Alertness/Sedation (OAA/S) scale $^{13}$ (appendix). With the same procedure, the $\mathrm{Cp}_{\mathrm{t}}$ of propofol was progressively increased in each patient until no reactions were observed after a light painful stimulus (squeezing the trapezius), ${ }^{13}$ while the $C \mathrm{p}_{t}$ of propofol required to produce each level of sedation was recorded. Standard monitoring was used during the study, including non-invasive arterial blood pressure,

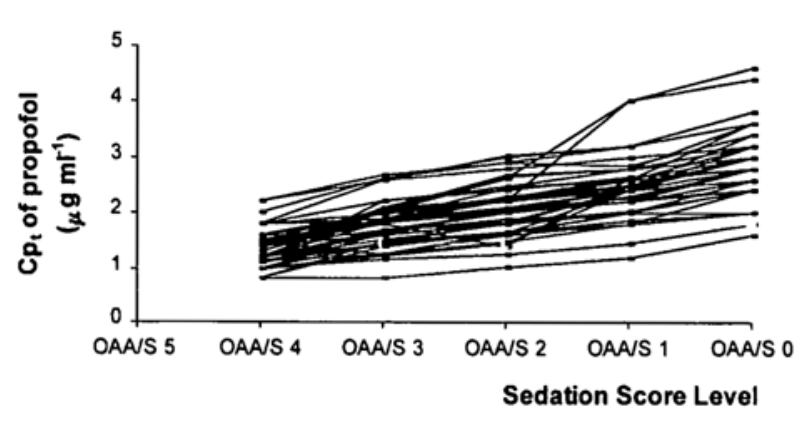

FIGURE 1 Plasma concentrations of propofol $\left(\mathrm{C}_{\mathrm{p}_{\mathrm{t}}}\right)$ recorded at each level of sedation are plotted for all studied patients.

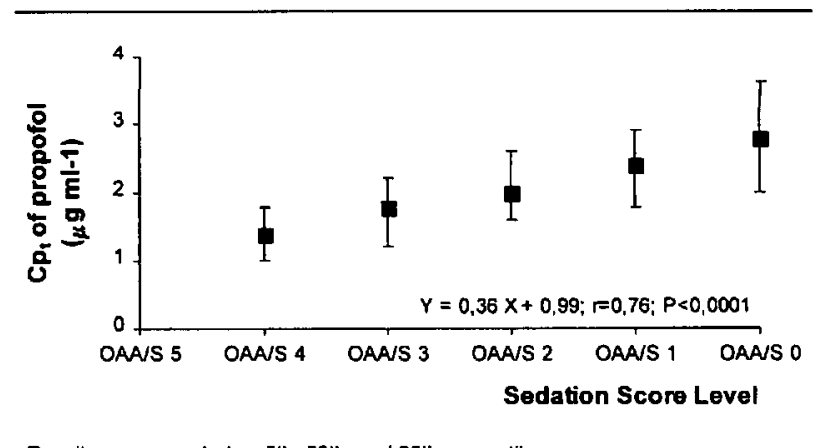

Results are presented as 5 th, 50 th, and 95th percentiles.

FIGURE 2 The 5th, 50th, and 95th percentiles of the plasma concentrations of propofol $\left(\mathrm{Cp}_{\mathrm{r}}\right)$ required to produce each level of sedation. Correlation between the levels of sedation and the $\mathrm{CP}_{\mathrm{t}}$ of propofol is also reported. 
heart rate and pulse oximetry. Oxygen was given by face mask $\left(\mathrm{FIO}_{2}=0.4\right)$ throughout the study. Apnea or decrease in pulse oximetry values $<90 \%$ were treated by assisting ventilation with a face mask, recording the need for ventilatory assistance.

Statistical analysis was performed using the program Stat-view 3.0 (Abacus Conc., Berkeley, USA). For each considered level of sedation the 5th, 50th and 95th percentiles of $\mathrm{Cp}_{\mathrm{t}}$ of propofol were calculated. Correlation and linear regression analysis were also used as indicated. A value of $P<0.05$ was considered as significant.

\section{Results}

The anthropometric characteristics of studied patients are shown in Table I.

In all patients the deepest level of sedation (no reaction after squeezing the trapezius) was achieved without clinically relevant complications. Three patients (5\%) showed mild coughing, and five $(8.3 \%)$ showed airway obstruction requiring the insertion of a Guedel cannula before the deepest $\mathrm{OAA} / \mathrm{S}$ level was achieved. However, in no case was apnea requiring ventilatory assistance reported.

No changes in hemodynamic variables were observed throughout the study.

The Figure 1 shows the $\mathrm{Cp}_{\mathrm{t}}$ of propofol required to produce the different levels of sedation in each studied patient. The mean $( \pm S D)$ plasma concentrations of propofol required to produce each level of sedation with $95 \%$ confidence intervals are reported in the

TABLE I Demographic data

\begin{tabular}{ll}
\hline Age $(\mathrm{yr})$ & $46 \pm 15$ \\
Weight $(\mathrm{kg})$ & $70 \pm 11$ \\
Height $(\mathrm{cm})$ & $170 \pm 8$ \\
ASA physical status & $\mathrm{I}(\mathrm{I}-\mathrm{II})$ \\
Malc/Femalc & $27 / 33$ \\
\hline
\end{tabular}

Continuous variables are presented as mean $( \pm S D)$, ordinal data are presented as median (range) or as number.
Table II, while the 5th, 50th, and 95th percentiles are shown in Figure 2. Correlation was also observed between the $\mathrm{Cp}_{\mathrm{t}}$ of propofol and the different levels of sedation $\mathrm{r}=0.76 ; P<0.0001$ ) (Figure 2 ).

\section{Discussion}

Due to its rapid and short-acting pharmacokinetic properties, propofol is a suitable drug for sedation..$^{1,2}$ This prospective investigation was conducted to assess the use of target-controlled infusion of propofol to produce different levels of sedation in a clinical context, and demonstrated that progressively increasing the $\mathrm{Cp}_{\mathrm{t}}$ of propofol allowed easy deepening of the level of sedation with clinically relevant hemodynamic and respiratory stability, probably due to the minimal risk for overdosing the drug with target-controlled infusion systems. Interestingly, after the steady state between plasma and effect-site calculated concentrations of propofol had been achieved, plasma concentrations of propofol ranging between 1.2 and 1.8 $\mu \mathrm{g} \cdot \mathrm{ml}^{-1}$ allowed patient arousal on verbal command with $95 \%$ confidence intervals. This observation is similar to previous findings of Oei-Lim and coworkers, ${ }^{14,15}$ who demonstrated that venous blood concentrations of propofol between 1.2 and $1.8 \mu \mathrm{g} \cdot \mathrm{ml}^{-1}$ were required to maintain conscious sedation during dental treatment. On the other hand, to produce heavy sedation (arousal with physical stimulation only) with 95\% confidence intervals, the $\mathrm{Cp}_{\mathrm{t}}$ of propofol had to be increased to $2-2.5 \mu \mathrm{g} / \mathrm{ml}$.

The use of computer-controlled infusions of propofol has been developed to overcome drawbacks of manual schemes of infusion, allowing an easier and more accurate achievement and maintenance of a desired blood concentration of propofol. ${ }^{4}$ Coetzee and colleagues ${ }^{16}$ have demonstrated that different pharmacokinetic sets may have an impact on the accuracy of target controlled infusion devices, when different pharmacokinetic parameter sets are used. The pharmacokinetic parameter set applied by the Diprifusor is derived from Marsh's modification of the Gepts model, ${ }^{10}$ and provides a median

TABLE II Mean ( $\left(\right.$ SD) and 95\% confidence intervals (C.I.) of plasma concentrations of propofol $\left(C_{P_{t}}\right)$ required to obtain each of the different levels of sedation according the Observer's Assessment of Alertness / Sedation (OAA/S) scale.

\begin{tabular}{|c|c|c|c|}
\hline$O A A / S$ score & $\begin{array}{l}\text { Responsiveness } \\
\text { category }\end{array}$ & $\begin{array}{l}\text { Cp, of propofol } \\
\left(\mu g \cdot m l^{-1}\right)\end{array}$ & $\begin{array}{l}95 \% \text { C.I. } \\
\left(\mu g \cdot m^{-1}\right)\end{array}$ \\
\hline 4 & Lethargic response to name spoken in normal tone & $1.3 \pm 0.33$ & $1.2 \cdot 1.4$ \\
\hline 3 & Responds only after name is called loudly and or repeatedly & $1.7 \pm 0.39$ & $1.6 \cdot 1.8$ \\
\hline 2 & Responds only after mild prodding or shaking & $2.0 \pm 0.4$ & $1.9-2.1$ \\
\hline 1 & Responds only after squeezing the trapezius & $2.4 \pm 0.5$ & $2.2-2.5$ \\
\hline 0 & Does not respond after squeezing the trapezius & $2.8 \pm 0.6$ & $2.6-3.0$ \\
\hline
\end{tabular}

Results are presented as mean $( \pm \mathrm{SD})$. 
performance error of $5.7 \%,{ }^{11}$ which can be considered to be acceptable for clinical practice. The pump software also displays the calculated effect-site concentration of propofol, allowing the anesthesiologist to optimize the time required to achieve equilibrium between the target plasma concentration set on the pump and the concentration calculated by the model at the effect site. Previous studies evaluating different techniques of propofol administration during monitored anesthesia care demonstrated that, although the overall quality of sedation, operating conditions and clinical recovery profiles were similar with different administration techniques, the anesthesiologist had to intervene more frequently with the intermittent bolus injection technique than either conventional syringe infusion or target-controlled infusion techniques. ${ }^{17}$ While it has been reported in large multicentre trials, that target-controlled infusion systems are easily learned and well accepted by anesthesiologists in their daily practice. ${ }^{18}$

A wide variety of objective clinical scoring systems has been developed to reduce individual observer bias and to provide a more consistent method of monitoring temporal changes in the level of sedation. ${ }^{19}$ The scale used in the present investigation, to evaluate the depth of sedation, is based on assessment in four separate categories (responsiveness, speech, facial expression and ocular appearance) and has been demonstrated to provide a high discriminatory power of the different levels of sedation. ${ }^{1,13}$ The OAA/S scale has also been validated against the Digit Symbol Substitution Test (a sensitive measure of cognitive and psychomotor impairment produced by sedative-hypnotic drugs), ${ }^{20}$ and can be considered suitable and easily reproducible to monitor sedation in a practical clinical context.

Since factors, such as concomitant administration of hypnotic and/or analgesic agents, are known to affect the plasma concentration of propofol required to induce and maintain general anesthesia, ${ }^{21,22}$ further clinical studies are required to assess the effects of premedication or analgesic supplementation on the $\mathrm{C}_{\mathrm{t}}$ of propofol required to maintain a desired level of sedation during monitored anesthesia care. However, from the present clinical evaluation it can be concluded that target-controlled infusion of propofol provides an ease and safe management of intraoperative sedation, allowing fast and predictable changes in the depth of sedation minimizing the risks of drug-related hemodynamic and respiratory side effects due to the minimal risk for propofol overdosing.

\section{Acknowledgments}

This study was supported by the IRCCS San Raffaele Hospital. Authors thank Fresenius Spa (Italy) for supply of the Diprifusor, as well as Dr. G. Crispigni (University Department of Orthopedic Surgery, IRCCS San Raffaele Hospital) and the staff of anesthesia nurses (University Department of Anesthesiology, IRCCS San Raffaele Hospital) without whose help and co-operation this study would not have been possible.

\section{References}

I Sá Régo $M M$, Watcha MF, White PF. The changing role of monitored anesthesia care in the ambulatory setting. Anesth Analg 1997; 85: 1020-36.

2 White PF, Negus JB. Sedative infusions during local and regional anesthesia: a comparison of midazolam and propofol. J Clin Anesth 1991; 3: 32-9.

3 Veselis RA, Reinsel RA, Feshchenko VA, Wronshi $M$. The comparative amnesic effects of midazolam, propofol, thiopental and fentanyl at equisedative concentrations. Anesthesiology 1997; 87: 749-64.

4 White M, Kenny GMC. Intravenous propofol anaesthesia using a computerised infusion system. Anaesthesia 1990; 45: $204-9$.

5 Russell D, Wilkes MP, Hunter SC, Glen JB, Hutton P, Kenny GNC. Manual compared with target- controlled infusion of propofol. Br J Anaesth 1995; 75: 562-6.

6 Swinhoe CE, Peacock JE, Glen JB, Reilly CS. Evaluation of the predictive performance of 'Diprifusor' TCI system. Anaesthesia 1998; 53(Suppl1): 61-7.

7 Fanelli G. Peripheral nerve block with electric neurostimulation. Minerva Anestesiol 1992; 58: 1025-6.

8 Fanelli G, Casati A, Beccaria P, et al. A double-blind comparison of ropivacaine, bupivacaine and mepivacaine during sciatic and femoral nerve blockade. Anesth Analg 1998; 87: 597-600.

9 Gepts E, Camu F, Cockshott ID, Douglas EJ. Disposition of propofol administered as constant rate intravenous infusions in humans. Anesth Analg 1987; 66: 1256-63.

10 Marsh B, White M, Morton N, Kenny GNC. Pharmacokinetic model driven infusion of propofol in children. Br J Anaesth 1991; 67: 41-8.

11 Glen JB. The development of 'Diprifusor': a TCI system for propofol. Anaesthesia 1998; 58(Suppl1): 13-21.

12 Glass PSA, Jacobs JR, Reves JG. Intravenous anesthetic delivery. In: Miller RD (Ed.). Anesthesia, 3rd ed. New York: Churchill Livingston, 1990: 367-88.

13 Chernik DA, Gillings $D$, Laine $H$, et al. Validity and reliability of the Observer's Assessment of Alertness/Scdation scale: study with intravenous midazolam. J Clin Psycopharmacol 1990; 10: 244-51.

14 Oei-Lim VLB, White M, Kalkman CJ, Engbers FHM, Makkes PC, Ooms WG. Pharmacokinetics of propofol during conscious sedation using target-controlled infusion in axious patients undergoing dental treatment. $\mathrm{Br}$ J Anaesth 1998; 80: 324-31. 
15 Oei-Lim VLB, Kalkman CJ, Makkes PC, Ooms WG.

Patient-controlled versus anesthesiologist-controlled conscious sedation with propofol for dental treatment in anxious patients. Anesth Analg 1998; 86: 967-72.

16 Coetzee JF, Glen JB, Wium CA, Boshoff $L$.

Pharmacokinetic model selection for target-controlled infusions of propofol. Assessment of three parameter sets. Anesthesiology 1995; 82: 1328-45.

17 Newson C, Joshi GP, Victory R, White PF. Comparison of propofol administration techniques for sedation during monitored anesthesia care. Anesth Analg 1995; 81 : 486-91.

18 Servin FS. TCI compared with manually controlled infusion of propofol: a multicentre study. Anaesthesia 1998; 58(Suppl1): 82-6.

19 Apramov $M N$, White PF. Methods for monitoring the level of sedation. Crit Care Clin 1995; 11: 803-26.

20 Johnson LC, Chernik DA. Sedative-hypnotics and human performance. Psychopharmacology 1982; 76: 101-13.

21 Struys $M$, Versicbelen $L$, Rolly $G$. Influence of pre-anaesthetic medication on target propofol concentration using a 'diprifusor' TCI system during ambulatory surgery. Anaesthesia 1998; 58(Suppl1): 68-71.

22 Servin FS, Marchand-Maillet F, Desmonts JM. Influence of analgesic supplementation on the target propofol concentrations for anaesthesia with 'Diprifusor' TCI. Anaesthesia 1998; 58(Suppl1): 72-6.

Appendix The Observer's Assessment of Alertness / Sedation scoring system (OAA/S). ${ }^{13}$

\begin{tabular}{|c|c|c|c|c|}
\hline \multicolumn{5}{|c|}{ Assessment Categories } \\
\hline Responsiveness & Speech & Facial expression & Eyes & $\begin{array}{l}\text { Score } \\
\text { Level }\end{array}$ \\
\hline $\begin{array}{l}\text { Responds readily to name } \\
\text { spoken in normal tone }\end{array}$ & Normal & Normal & Clear, no ptosis & 5 \\
\hline $\begin{array}{l}\text { Lethargic response to name } \\
\text { spoken in normal tone }\end{array}$ & Mild slowing or thickening & Mild relaxation & $\begin{array}{l}\text { Glazed or mild ptosis } \\
\text { (less than half the eye) }\end{array}$ & 4 \\
\hline $\begin{array}{l}\text { Responds only after name is called } \\
\text { loudly and or repeatedly }\end{array}$ & Slurring or prominent slowing & Marked relaxation & $\begin{array}{l}\text { Glazed and marked ptosis } \\
\text { ( } z \text { half the eye) }\end{array}$ & 3 \\
\hline $\begin{array}{l}\text { Responds only after mild } \\
\text { prodding or shaking }\end{array}$ & Few recognizable words & & & 2 \\
\hline $\begin{array}{l}\text { Responds only after squeezing } \\
\text { the trapezius }\end{array}$ & & & & 1 \\
\hline $\begin{array}{l}\text { Does not respond after squeezing } \\
\text { the trapezius }\end{array}$ & & & & 0 \\
\hline
\end{tabular}

